\title{
Article \\ A Cyanobacteria-Based Biofilm System for Advanced Brewery Wastewater Treatment
}

\author{
Konstantinos P. Papadopoulos ${ }^{1}$, Christina N. Economou ${ }^{1, *}$, Athanasia G. Tekerlekopoulou ${ }^{2}$ (i) \\ and Dimitris V. Vayenas 1,3 \\ 1 Department of Chemical Engineering, University of Patras, Rio, GR-26504 Patras, \\ Greece; cmng3492@upnet.gr (K.P.P.); dvagenas@chemeng.upatras.gr (D.V.V.) \\ 2 Department of Environmental Engineering, University of Patras, 2 G. Seferi Str., GR-30100 Agrinio, Greece; \\ atekerle@upatras.gr \\ 3 Institute of Chemical Engineering Sciences (ICE-HT), Stadiou Str., Platani, GR-26504 Patras, Greece \\ * Correspondence: economch@upatras.gr; Tel.: +30-2610-962749
}

check for updates

Citation: Papadopoulos, K.P.; Economou, C.N.; Tekerlekopoulou, A.G.; Vayenas, D.V. A

Cyanobacteria-Based Biofilm System for Advanced Brewery Wastewater Treatment. Appl. Sci. 2021, 11, 174. https://dx.doi.org/

10.3390/app11010174

Received: 19 November 2020

Accepted: 24 December 2020

Published: 27 December 2020

Publisher's Note: MDPI stays neutral with regard to jurisdictional claims in published maps and institutional affiliations.

Copyright: (C) 2020 by the authors. Licensee MDPI, Basel, Switzerland. This article is an open access article distributed under the terms and conditions of the Creative Commons Attribution (CC BY) license (https: / / creativecommons.org/ licenses/by/4.0/).
Featured Application: Post-treatment of brewery wastewater through an attached cyanobacterial growth system with simultaneous production of bioethanol.

\begin{abstract}
Algal/cyanobacterial biofilm photobioreactors provide an alternative technology to conventional photosynthetic systems for wastewater treatment based on high biomass production and easy biomass harvesting at low cost. This study introduces a novel cyanobacteria-based biofilm photobioreactor and assesses its performance in post-treatment of brewery wastewater and biomass production. Two different supporting materials (glass/polyurethane) were tested to investigate the effect of surface hydrophobicity on biomass attachment and overall reactor performance. The reactor exhibited high removal efficiency (over 65\%) of the wastewater's pollutants (chemical oxygen demand, nitrate, nitrite, ammonium, orthophosphate, and total Kjeldahl nitrogen), while biomass per reactor surface reached 13.1 and $12.8 \mathrm{~g} \cdot \mathrm{m}^{-2}$ corresponding to 406 and $392 \mathrm{mg} \cdot \mathrm{L}^{-1}$ for glass and polyurethane, respectively, after 15 days of cultivation. The hydrophilic glass surface favored initial biomass adhesion, although eventually both materials yielded complete biomass attachment, highlighting that cell-to-cell interactions are the dominant adhesion mechanism in mature biofilms. It was also found that the biofilm accumulated up to $61 \%$ of its dry weight in carbohydrates at the end of cultivation, thus making the produced biomass a suitable feedstock for bioethanol production.
\end{abstract}

Keywords: Leptolyngbya sp.; attached growth; brewery wastewater; carbohydrates; bioremediation; supporting materials; hydrophobicity; attachment efficiency; biofilm photobioreactor

\section{Introduction}

The cultivation of photosynthetic microorganisms (microalgae and cyanobacteria) to produce a wide range of high value products such as pigments, proteins, polysaccharides, vitamins, and fatty acids [1], as well as electricity in bioelectrochemical systems [2], has been investigated extensively. Wastewater treatment systems utilizing photosynthetic microorganisms have recently emerged as a promising alternative to conventional biological processes such as activated sludge [3]. However, the treatment of agro-industrial, industrial and domestic wastewaters with algae/cyanobacteria has gathered significant research interest over the last decade and produced promising results in both organic and inorganic pollutant removal [4-9]. This method offers several advantages, such as reduced operational cost as photosynthesis replaces mechanical aeration requirements, decreased $\mathrm{CO}_{2}$ emissions [10], and the high cost of using chemical fertilizers for microalgal growth is avoided since microorganisms use the nutrients contained in the wastewaters [11]. Additionally, the produced biomass can be utilized as a platform for liquid (i.e., biodiesel and bioethanol) and gaseous (i.e., methane and biohythane) biofuels $[1,11,12]$. Brewery 
wastewaters are produced in high quantities (3-10 L per L of beer produced) from beer brewing processing industries worldwide [13] and in 2019 the total global beer production amounted to about 1.91 billion hectoliters [14]. Brewery wastewaters are characterized by significant organic (2000-6000 $\mathrm{mg} \cdot \mathrm{L}^{-1}$ of chemical oxygen demand, COD), nitrogen and phosphorous loadings (25-80 and 10-15 $\mathrm{mg} \cdot \mathrm{L}^{-1}$, respectively) and they have been traditionally treated aerobically $[13,15]$. Until today, a limited number of studies on brewery wastewater treatment using axenic microalgal cultures $[6,16]$ have been conducted in suspended cultivation systems. Recently, brewery wastewater was treated by our research group using a cyanobacterial-bacterial consortium dominated by the filamentous cyanobacterium Leptolyngbya sp. either without pre-treatment $[4,5]$ or after pre-treatment with electrocoagulation $[4,5]$.

Biomass harvesting/processing is often a challenging task. Photosynthetic culture cell densities are typically low (as low as $0.5 \mathrm{~g} \cdot \mathrm{L}^{-1}$ in conventional open pond photobioreactors [17]) and separation methods such as chemical flocculation, gravitational sedimentation, filtration, and centrifugation can be complex, time-consuming, or expensive $[3,18]$. Techno-economic analyses indicate that the cost of algal/cyanobacterial biomass harvesting and dewatering can amount to $20-30 \%$ of the total cultivation expenses in high-rate algal ponds $[17,19]$.

The introduction of attached cultivation (biofilm) systems could be a step towards addressing these issues. Biofilms are microbial communities living in a self-produced matrix of extracellular polymeric substances (EPSs) that provide structural integrity and mediate their adhesion to surfaces [20]. Under nutrient limitation and sufficient irradiation/carbon, cyanobacteria tend to over exceed their typical carbohydrate content in the form of EPSs, instead of channeling energy towards cell synthesis ("carbon overflow" metabolism) [20,21]. Along with lower quantities of secreted proteins and nucleic acids, EPSs allow high cell density colonization of abiotic and biotic surfaces through hydrophobic or hydrophilic cellcell and cell-surface interactions [20]. These properties enable efficient biomass harvesting by scraping [22], as biofilms have a similar consistency to centrifuged biomass [23].

Algal/cyanobacterial biofilms also show high potential in wastewater treatment applications. The biofilm matrix is typically dominated by synergistic micro-consortia and protects microbial populations from exogenous environmental stresses (dehydration, antibiotics, chemicals, heavy metals, UV radiation, protozoan predators, etc.) $[20,24]$. Therefore, the microenvironment formed is less vulnerable to toxicity and variations in wastewater composition. Due to these attributes, several photosynthetic biofilm systems have been reported to increase pollutant removal rates and biomass production performance compared to suspended cultivation systems $[25,26]$. Moreover, the structural integrity and viscoelasticity [27] of biofilms minimizes the amount of residual biomass that ends up in the cultivation system outlet [28], thus reducing secondary pollution and disinfection costs [28]. However, the complexity of photosynthetic biofilms entails standardization and the scalability of this technology remains a considerable challenge. It is crucial that further research is carried out on the physicochemical/biological mechanisms that take place and establishing reactor design guidelines (geometry, growth surface materials, etc.).

This study introduces for the first time in the literature a simple cyanobacterial biofilm system designed for the post-treatment of biologically-treated, via the activated sludge process, brewery wastewater. This technology provides a viable alternative to conventional brewery wastewater treatment setups. The flat-plate, semi-immersed, photobioreactor was designed for the attachment of a microbial consortium dominated by the filamentous cyanobacterium Leptolyngbya sp. and the effectiveness of the biofilm system was compared in terms of pollutant removal and biomass production to suspended culture systems using the same Leptolyngbya-based microbial consortium [2] to treat brewery wastewater. The attached microbial mass was also characterized in terms of carbohydrates, proteins, and lipids to evaluate its potential in future applications. Moreover, two different biofilm reactor surfaces (glass and polyurethane) were tested to investigate the effect of 
substratum hydrophobicity on microbial attachment and growth, a subject of debate in the literature [29].

\section{Materials and Methods}

\subsection{Wastewater Characterization}

The brewery wastewater used in this study was collected from a local brewery (Patras industrial zone, Greece). It was treated aerobically in the brewery's activated sludge wastewater treatment facility, before being discharged into the central wastewater treatment unit of the industrial zone. After sampling from the outlet of the unit's secondary settling tank, the wastewaters were filtered through $0.45 \mu \mathrm{m}$ pore membrane filters to remove suspended solids and then stored at $-20{ }^{\circ} \mathrm{C}$ until use. The filtered wastewaters were analyzed for dissolved chemical oxygen demand (d-COD), nitrate $\left(\mathrm{NO}_{3}{ }^{-}-\mathrm{N}\right)$, nitrite $\left(\mathrm{NO}_{2}{ }^{-}\right.$$\mathrm{N})$, ammonium $\left(\mathrm{NH}_{4}{ }^{+}-\mathrm{N}\right)$, orthophosphate $\left(\mathrm{PO}_{4}{ }^{3-}-\mathrm{P}\right)$, total Kjeldahl nitrogen (TKN) and $\mathrm{pH}$, according to Standard Methods [30]. The $\mathrm{pH}$ values were determined with a HANNA HI 5521 multiparameter instrument (Table 1).

Table 1. Physicochemical characterization of the treated brewery wastewater.

\begin{tabular}{ccc}
\hline Parameter & Concentration & Units \\
\hline $\mathrm{d}-\mathrm{COD}$ & $190 \pm 10$ & $\mathrm{mg} \cdot \mathrm{L}^{-1}$ \\
$\mathrm{NO}_{3}{ }^{-}-\mathrm{N}$ & $16 \pm 0.5$ & $\mathrm{mg} \cdot \mathrm{L}^{-1}$ \\
$\mathrm{NH}_{4}{ }^{+}-\mathrm{N}$ & $5 \pm 0.7$ & $\mathrm{mg} \cdot \mathrm{L}^{-1}$ \\
$\mathrm{TKN}^{\mathrm{N}}$ & $15 \pm 0.9$ & $\mathrm{mg} \cdot \mathrm{L}^{-1}$ \\
$\mathrm{PO}_{4}{ }^{-}-\mathrm{P}$ & $5 \pm 0.3$ & $\mathrm{mg} \cdot \mathrm{L}^{-1}$ \\
$\mathrm{pH}$ & 8.5 & - \\
\hline
\end{tabular}

\subsection{Culture Identification and Inoculum Preparation}

Microbial samples were collected from the secondary settling tank of the wastewater treatment plant of Patras University's and were cultivated autotrophically in a nutrient medium (containing (in mg. $\mathrm{L}^{-1}$ ) $\mathrm{KNO}_{3}, 200 ; \mathrm{MgSO}_{4} \cdot 7 \mathrm{H}_{2} \mathrm{O}, 100 ; \mathrm{CaCl}_{2} \cdot 2 \mathrm{H}_{2} \mathrm{O}, 50$; $\left.\mathrm{K}_{2} \mathrm{HPO}_{4}, 108 ; \mathrm{KH}_{2} \mathrm{PO}_{4}, 56\right)$ suitable for algae/cyanobacteria enrichment [31]. The samples were cultivated for approximately 30 days under constant illumination of 2000 lux (or $27 \mu \mathrm{mol} \mathrm{m} \mathrm{m}^{-2} \mathrm{~s}^{-1}$ ) provided by two cool white lamps (Phillips, $120 \mathrm{~cm}, 36 \mathrm{~W}$ ), without any mechanical air supply. Temperature ranged between 24 and $26{ }^{\circ} \mathrm{C}$ and $\mathrm{pH}$ gradually rose from 7 to 9 .

After the initial cultivation period, a microbial consortium consisting of mixotrophic aggregates was obtained. Samples of the microbial culture were placed in sedimentation chambers and, using phase contrast and epifluorescence microscopy (Nikon Eclipse SE 2000 microscope), two cyanobacterial species were identified. Leptolyngbya sp. filaments in aggregate form dominated the culture (relative biomass fraction: $85 \%$ ), while a second Chroococcus-like population (relative biomass fraction: $5 \%$ ) was also identified. The culture also contained a significant number of heterotrophic bacteria and protozoa (relative biomass fraction: $10 \%$ ). Microbial population percentages are expressed as fractions of the total biomass of the microbial community, including cyanobacteria filaments and large-sized heterotrophic bacteria $(1-2 \mu \mathrm{m})[4,5]$. The culture was then acclimatized in the brewery wastewater (Section 2.1), under agitation and the conditions described above, without any significant alterations in microbial population composition. This culture was used as an inoculum for all experiments when in the mid-exponential growth phase (biomass concentration of $300 \mathrm{mg} \cdot \mathrm{L}^{-1}$ ).

\subsection{Experimental Apparatus}

The experiments were conducted in a flat-plate photobioreactor with constant wastewater recirculation to establish the formation of a liquid film that semi-immersed the biomass within the wastewater medium. A scheme of the biofilm photobioreactor setup is presented in Figure 1. It consisted of a $0.5 \mathrm{~L}$ magnetically stirred glass buffer vessel and a 
tilted plexiglass structure ( $5^{\circ}$ slope) that supported biofilm growth surfaces of $300 \mathrm{~cm}^{2}$ $(30 \times 10 \mathrm{~cm})$. Two different substratum materials of different physical properties where used: glass (hydrophilic) and commercial, non-porous, polyurethane (strongly hydrophobic), to investigate the effect of surface hydrophobicity on biofilm formation. Wastewater recirculation was provided by a peristaltic pump (Ismatec, BV-GES) and $5 \mathrm{~mm}$ diameter silicon tubes.

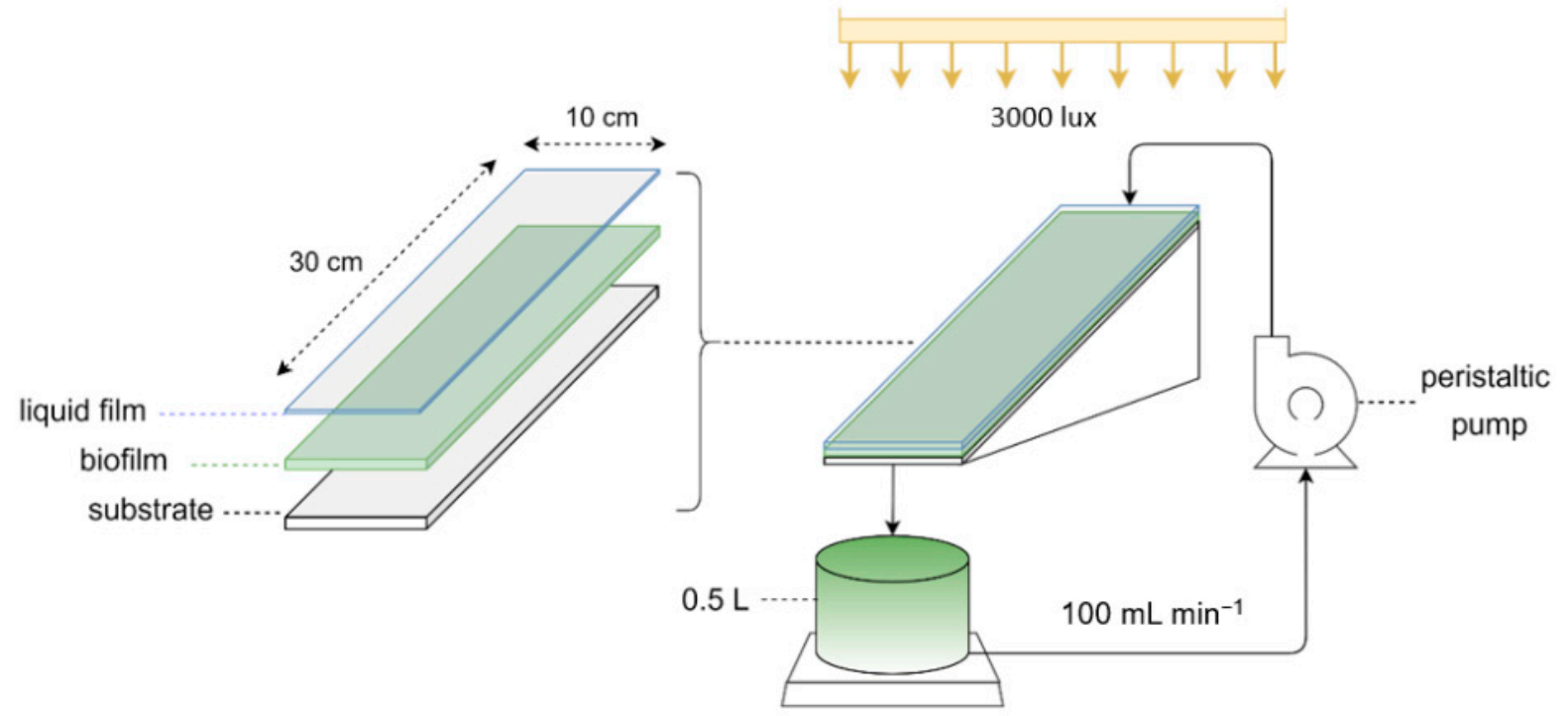

Figure 1. Schematic representation of the experimental setup.

Initially, the buffer vessel contained $0.5 \mathrm{~L}$ of culture $(90 \% v / v$ brewery wastewater medium and 10\% v/v inoculum prepared as described in Section 2.2). At the start of each experiment, the peristaltic pump was activated, generating a recirculating flow of $100 \mathrm{~mL} \cdot \mathrm{min}^{-1}$ from the buffer vessel towards the top of the tilting structure. The culture medium flowed through three nozzles towards the bottom end of the structure, forming a thin liquid film over the tilted surfaces (Figure 1) and then drained back into the buffer vessel. Water losses due to evaporation were compensated for by the addition of distilled water into the recirculation system.

Both experimental setups were under constant average irradiance of $41 \mu \mathrm{mol} \mathrm{m}{ }^{-2} \mathrm{~s}^{-1}$ (3000 lux) generated by fluorescent lamps (Phillips, $120 \mathrm{~cm}, 36 \mathrm{~W}$ ) placed above the apparatus. Temperature ranged between 24 and $26^{\circ} \mathrm{C}$, while $\mathrm{pH}$ was not adjusted as the wastewater's initial value of 8.5 was considered favorable for cyanobacterial cultivation. Changes in $\mathrm{pH}$ and temperature conditions were monitored using a HANNA HI 5521 multiparameter instrument.

\subsection{Determination of Total Biomass \& Nutrient Concentrations}

To determine pollutant and suspended biomass concentrations, samples were taken from the stirred buffer vessel. Total suspended biomass concentration (expressed as total suspended solids, TSS) was determined by filtration through $0.45 \mu \mathrm{m}$ pore membrane filters [30]. The filtrate was analyzed for dissolved chemical oxygen demand (d-COD), nitrate $\left(\mathrm{NO}_{3}{ }^{-}-\mathrm{N}\right)$, nitrite $\left(\mathrm{NO}_{2}{ }^{-}-\mathrm{N}\right)$, ammonium $\left(\mathrm{NH}_{4}{ }^{+}-\mathrm{N}\right)$, orthophosphate $\left(\mathrm{PO}_{4}{ }^{3-}-\mathrm{P}\right)$, total Kjeldahl nitrogen (TN), and $\mathrm{pH}$ according to Standard Methods [30].

To estimate the amount of biomass that adhered to the biofilm reactor surface, two $1 \mathrm{~cm}$-wide strips of attached biomass were carefully scraped using a hand scraper. The obtained biomass was then re-suspended in $10 \mathrm{~mL}$ of distilled water, stirred, and subsequently filtered through $0.45 \mu \mathrm{m}$ pore membrane filters for total biomass determination [30]. The obtained concentration was converted to biomass per biofilm area. The total amount of biomass produced in the biofilm setup was calculated by summing the suspended 
and attached fractions of biomass per reactor working volume. Similarly, percentages of attached biomass (attachment efficiency) were calculated by dividing the attached biomass by the total amount of biomass.

\subsection{Biomass Harvesting and Determination of Intracellular Compounds}

After the end of each experiment, the treated wastewater was drained into the buffer vessel and biomass was harvested from the growth surface by scraping. After re-suspension in $50 \mathrm{~mL}$ of distilled water, it was centrifuged, washed twice to remove nutrient residues and other impurities, and dried overnight at $105^{\circ} \mathrm{C}$. Previous studies utilizing the same Leptolyngbya-based microbial consortium have shown that it accumulates up to $40 \%$ of its dry biomass weight in carbohydrates [4,5], and for this reason carbohydrates were chosen as the target biomass compound of the present study. Intracellular sugar content (expressed as glucose equivalents) was estimated photometrically according to Dubois et al. [32]. Firstly, $1 \mathrm{mg}$ of dried biomass reduced to powder was mixed with $5 \mathrm{~mL}$ of distilled water. Then, $1 \mathrm{~mL}$ of this suspension was then mixed with $1 \mathrm{~mL}$ of $5 \%(w / v)$ phenol solution and $5 \mathrm{~mL}$ sulfuric acid solution and measured at $490 \mathrm{~nm}$ after $30 \mathrm{~min}$ [4,5,32]. To determine protein content, $10 \mathrm{mg}$ of dried harvested biomass were suspended into $5 \mathrm{~mL}$ of phosphate buffer solution ( $\mathrm{pH}=7.3$ ). The resulting suspension was sonicated for $40 \mathrm{~min}$ in a sonication bath (Julabo USR 3) for cell lysis [4,5,33]. After filtering through a $0.45 \mu \mathrm{m}$ pore membrane filter, the protein content was determined following Bradford [34]. To measure lipid content, $20 \mathrm{mg}$ of dried biomass underwent extraction with 2:1 (v/v) mixture of chloroform and methanol, washing with $0.88 \%(w / v) \mathrm{KCl}$ solution, and drying over anhydrous $\mathrm{Na}_{2} \mathrm{SO}_{4}$. The solvent was evaporated, and the extracted oil was quantified gravimetrically $[4,5,35]$.

\subsection{Statistical Analysis}

All analyses were carried out in duplicate with a relative standard deviation not exceeding 5\%. Results were expressed as mean \pm standard deviation. Statistically significant differences between data were evaluated using the t-student confidence interval for $95 \%$ probability. In this statistical analysis, the data were assumed to follow the t-student distribution and the confidence interval for the difference of a pair of mean values was calculated.

\section{Results \& Discussion}

\subsection{Attachment Efficiency}

After activating the wastewater recirculation system, the culture started flowing over the inclined biofilm surface initiating adhesion and biofilm formation. A different initial adhesion rate was observed for the two surface materials tested (Figure 2). In the case of glass, which is a mildly hydrophilic material [36], biomass attachment was rapid and efficient, surpassing $90 \%$ after two days of cultivation. On the contrary, adhesion on the polyurethane surface did not occur at an equally high rate, as after two days of cultivation $42.6 \%$ of the total biomass remained in suspension. Following this initial adhesion phase, the fraction of biomass that remained attached exceeded $98.3 \%$ and $97.4 \%$ for glass and polyurethane, respectively, nine (9) days into the experiments. At the end of cultivation, both experiments exhibited complete biomass attachment ( $>99 \%$ ), while statistically significant differences on biomass attachment were not observed between the two surface materials.

There have been conflicting reports on whether hydrophobic or hydrophilic surfaces enhance adhesion [28,29,36]. Hydrophobic surfaces are generally considered more susceptible to biofilm formation; however, factors such as surface roughness, wettability, hydrodynamics, and the nature of EPSs produced by the microorganisms play equally important roles $[29,36,37]$. In this study, the more hydrophilic surface (glass) favored initial adhesion; thus, it is recommended for attached cultivation of Leptolyngbya sp. This finding could indicate that the Leptolyngbya-based consortium utilized in this study produces EPSs of a mostly hydrophilic nature. Various species of cyanobacteria have been reported to se- 
crete hydrocolloidal EPSs which draw extensive research interest due to their applications in the bio-materials field (hydrogels, etc.) [38].

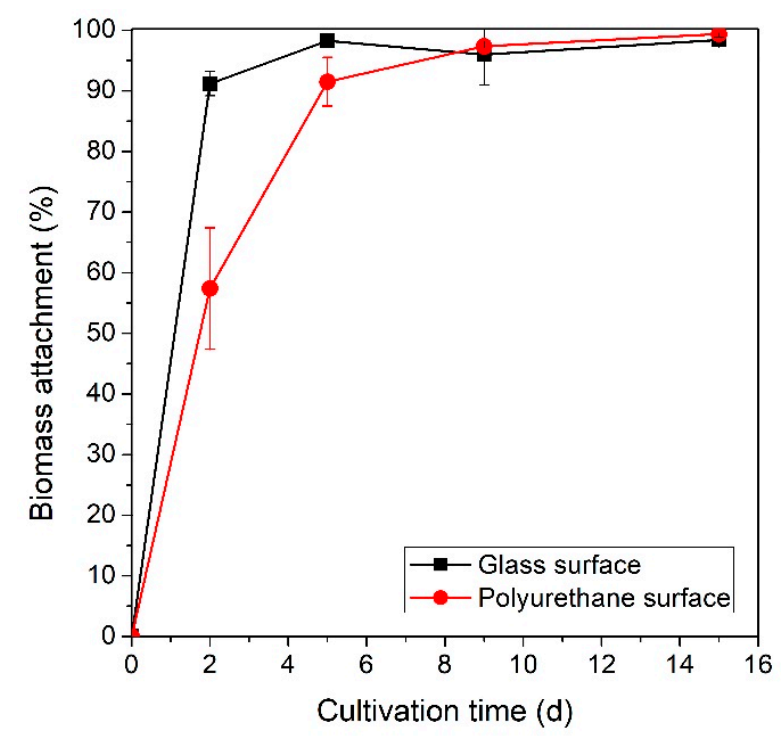

Figure 2. Percentage of total biomass that attached to the biofilm growth surfaces (glass and polyurethane) over time.

The predominant role of EPSs and cell-to-cell interactions in biofilm formation is further indicated by the high attachment efficiency after the initial adhesion phase. The microbial community appeared to create an EPS/cell "coating" on the substratum surface, negating its impact on adhesion efficiency. Similar amounts of biomass remained attached on both materials after this point as the biofilm matured (irreversible adhesion). Mazumder et al. reported that microbial accumulation on surfaces can significantly decrease their hydrophobicity and binding characteristics [39].

\subsection{Pollutant Removal}

Although primary aerobic wastewater treatment is generally effective at removing organic pollutants, it often does not reduce inorganic pollutant concentrations (especially phosphorus) to a level that allows safe disposal or reuse and, therefore, requires secondary physicochemical treatment [40]. The post-treatment biofilm reactor introduced in this study aims to effectively remove residual pollutant concentrations for safe effluent disposal. Figure 3a presents the results of $\mathrm{NO}_{3}{ }^{-}-\mathrm{N}, \mathrm{NH}_{4}{ }^{+}-\mathrm{N}$, and $\mathrm{PO}_{4}{ }^{3-}$-Premoval over the course of the 15-day cultivation period. Similar inorganic pollutant removal rates and no statistically significant differences were observed for both surface materials used. $\mathrm{NH}_{4}{ }^{+}-\mathrm{N}$ is usually the preferred nitrogen substrate for cyanobacterial cultivation as its assimilation is less energy demanding and, in this study, was rapidly consumed after two days of cultivation [41]. However, it should be noted that under the alkaline $\mathrm{pH}$ conditions of these experiments ( $\mathrm{pH}$ rose from 8.5 to 9.45) a large fraction of the initial ammonium concentration evaporated in the form of ammonia gas [41]. $\mathrm{NO}_{3}{ }^{-}-\mathrm{N}$ gradually reduced by $67.0 \%$ (glass) and $67.6 \%$ (polyurethane) within the first ten days of cultivation, while TKN concentration followed a similar trend as, in both cases, its concentration dropped below $5 \mathrm{mg} \cdot \mathrm{L}^{-1}$. It is worth noting that $\mathrm{NO}_{2}-\mathrm{N}$ concentrations did not exceed $0.05 \mathrm{mg} \cdot \mathrm{L}^{-1}$ at any point during the experiments. The microbial consortium was also effective at removing phosphorus compounds. $\mathrm{PO}_{4}{ }^{3-}$. Pconcentrations reduced by $76.2 \%$ and $75.5 \%$ for the glass and polyurethane growth surfaces, respectively. After post-treatment, all pollutant concentrations were found to comply with European regulations for effluent disposal (Articles 4 and 5 of the Urban Wastewater Directive, 91/271/EEC) [42]. 


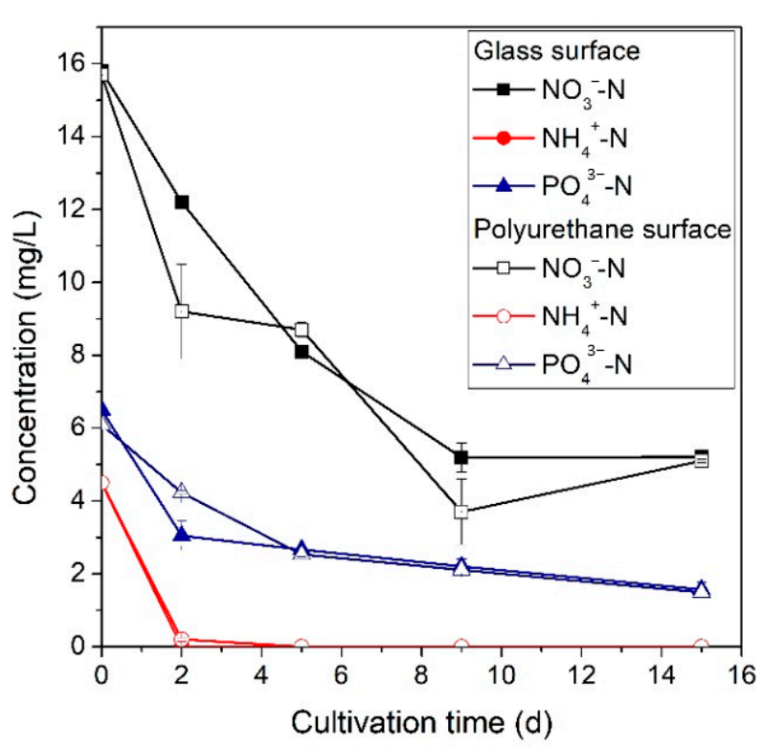

(a)

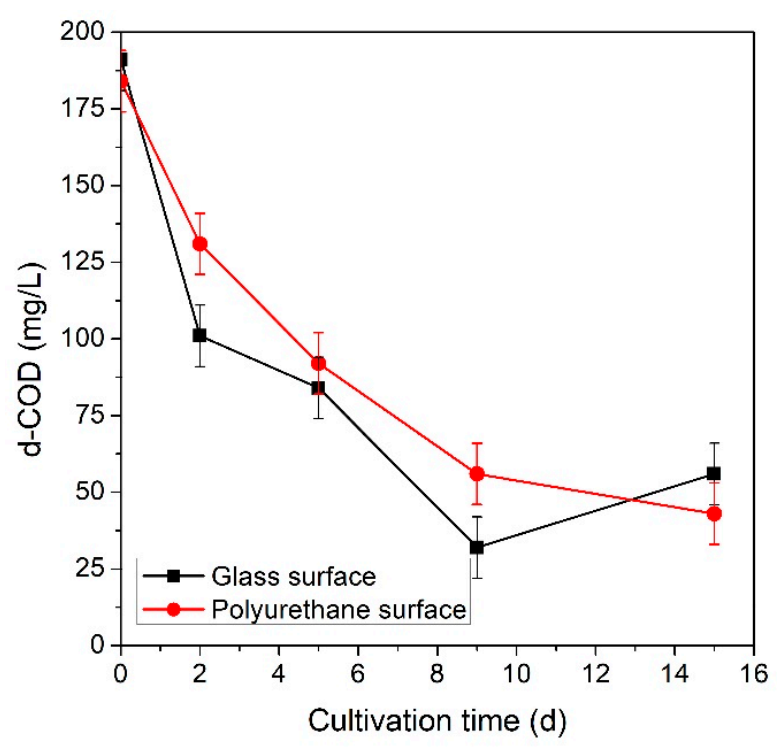

(b)

Figure 3. Bulk (a) inorganic $\left(\mathrm{NO}_{3}{ }^{-}-\mathrm{N}, \mathrm{NH}_{4}{ }^{+}-\mathrm{N}\right.$ and $\left.\mathrm{PO}_{4}{ }^{3-}-\mathrm{P}\right)$ and (b) organic (d-COD) pollutant concentrations for glass and polyurethane growth surfaces over time.

In absence of an external mechanical $\mathrm{CO}_{2}$ feed, the microbial consortium utilized organic pollutants as its primary carbon source. In the case of the glass growth surface, $71.6 \%$ of the initial d-COD was removed, while for polyurethane the corresponding removal percentage was $76.2 \%$ (Figure $3 b$ ). Note that statistically significant differences in d-COD removal rates were not observed between the two surface materials. Leptolyngbya sp. is known to be a mixotrophic cyanobacterium and for this reason it has been utilized for treatment of wastewaters containing high concentrations of organic pollutants in past research $[4,5,43,44]$. Tsolcha et al. investigated the performance of a Leptolyngbyabased mixotrophic culture in the treatment of various agro-industrial wastewaters (cheese whey, poplar sawdust, and grass hydrolysates) containing d-COD concentrations of up to $3660 \mathrm{mg} \cdot \mathrm{L}^{-1}$ and recorded removal percentages of up to $93 \%$ without the provision of an additional inorganic carbon source [44].

Table 2 presents pollutant removal percentages of the present study compared to those obtained by Papadopoulos et al., who investigated post-treatment of the same wastewater using a suspended Leptolyngbya-based culture under identical $\mathrm{pH}$, light, and temperature conditions [4]. The biofilm photobioreactor manages to equal or exceed all the removal percentages recorded in suspended cultivation. The greatest deviation between the two cultivation systems is in d-COD removal. Specifically, in attached cultivation $70-83 \%$ of the initial d-COD was removed within nine (9) days, in comparison to $24 \%$ in suspended cultivation over the same period. This behavior can be interpreted if the secretion of EPSs is considered. Under nitrogen limitation, which occurred throughout the experiments, cyanobacteria produce exopolysaccharides and other slowly biodegradable macromolecules $[20,21]$ that add to the existing organic loading of the wastewater, thus reducing observed d-COD removal rates as cultivation progresses. Namely, Papadopoulos et al. documented an extracellular polysaccharide concentration as high as $80 \mathrm{mg} \cdot \mathrm{L}^{-1}$ in nitrogen limitation conditions [4]. On the contrary, in the case of the biofilm reactor, it is hypothesized that a large fraction of these EPSs remained bound within the biofilm matrix resulting in a higher COD removal rate. 
Table 2. Pollutant removal percentages after nine (9) days of attached cultivation (glass and polyurethane growth surfaces) and suspended cultivation ${ }^{1}$.

\begin{tabular}{cccc}
\hline & \multicolumn{3}{c}{ Removal (\%) } \\
\cline { 2 - 3 } Substance & \multicolumn{2}{c}{ Attached Cultivation } & $\begin{array}{c}\text { Suspended } \\
\text { Cultivation }\end{array}$ \\
\cline { 2 - 3 } & Glass & Polyurethane & 50.0 \\
\cline { 2 - 3 } $\mathrm{NO}_{3}{ }^{-}-\mathrm{N}$ & 67.2 & 76.5 & 100 \\
$\mathrm{NH}_{4}{ }^{+}-\mathrm{N}$ & 100 & 100 & 57.0 \\
$\mathrm{PO}_{4}{ }^{3-}-\mathrm{P}$ & 66.0 & 65.4 & 24.0 \\
$\mathrm{~d}-\mathrm{COD}$ & 83.2 & 70.7 & \\
\hline
\end{tabular}

${ }^{1}$ Adapted by Papadopoulos et al. (2020) [4].

\subsection{Biomass Production}

The sum of suspended and attached biomass per reactor working volume and reactor growth surface over the course of the 15-day cultivation period is presented in Figure 4. Similar growth rates were observed for both growth surface materials tested, although the use of a glass growth substratum appears to slightly enhance biomass growth in comparison to polyurethane. The corresponding maximum growth rates were $66 \mathrm{mg} \cdot \mathrm{L}^{-1} \cdot \mathrm{d}^{-1}$ (glass) and $59 \mathrm{mg} \cdot \mathrm{L}^{-1} \cdot \mathrm{d}^{-1}$ (polyurethane). After an exponential growth phase during the first 6-10 days of cultivation, total biomass concentration stabilized at around $406 \mathrm{mg} \cdot \mathrm{L}^{-1}$ for glass and $392 \mathrm{mg} \cdot \mathrm{L}^{-1}$ for polyurethane. In terms of attached biomass per biofilm surface area, the respective calculated values were 13.1 and $12.8 \mathrm{~g} \cdot \mathrm{m}^{-2}$.

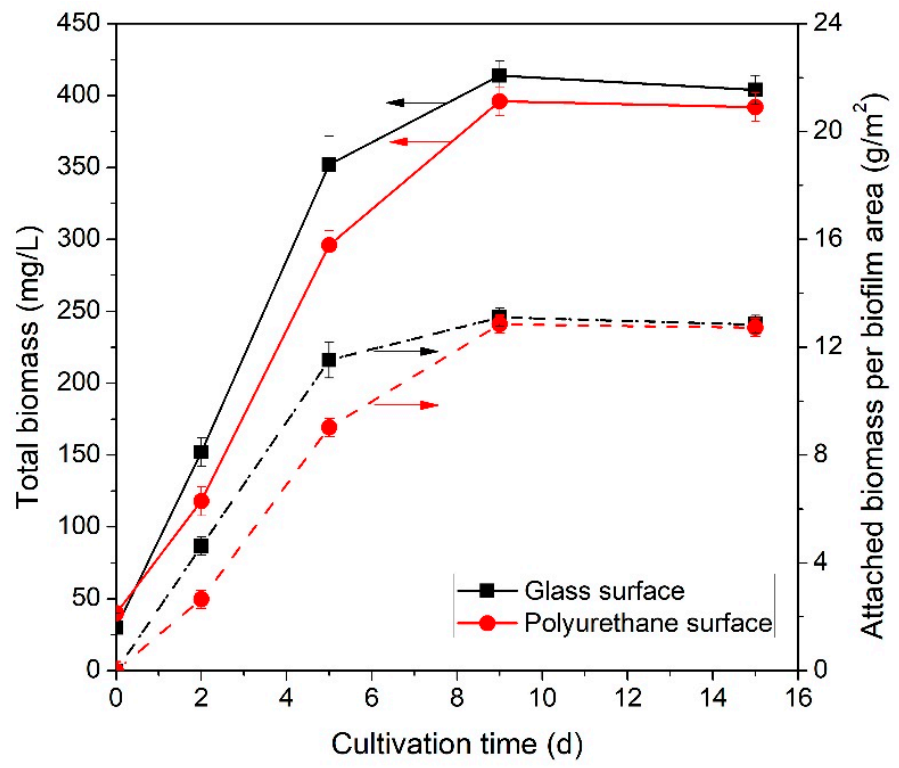

Figure 4. Total biomass concentration per working reactor volume (left $y$-axis) and reactor surface area (right $y$-axis) over cultivation time for glass and polyurethane growth surface materials.

The work of Papadopoulos et al. [4] provides a reference point to assess the performance of the biofilm reactor introduced in the present study. Both biofilm setups (glass/polyurethane surfaces) significantly enhanced biomass growth rates compared to suspended cultivation. Specifically, on the ninth day of cultivation the suspended culture produced $360 \mathrm{mg} \cdot \mathrm{L}^{-1}$, i.e., $11 \%$ less than the biofilm cultivation experiments. Biofilms have been reported to enhance biomass growth in many studies [28]. For example, Gao et al. studied synthetic secondary effluent treatment using $\mathrm{CO}_{2}$-aerated attached and suspended growth membrane bioreactors and reported a significant increase in biomass productivity and nutrient removal in the case of the biofilm reactor [26]. Similarly, Huang et al. compared the performance of a membrane biofilm photobioreactor to a suspended growth 
setup utilizing the same BG-11 cultivation medium and reported a $30 \%$ increase in biomass productivity when using biofilm reactors [45]. In this study, it is suspected that the thin water film flowing above the biofilm surface enables more efficient $\mathrm{CO}_{2}$ transfer between the gas (atmosphere) and liquid phases thus providing an additional inorganic carbon source. On the contrary, in cultures that are fully immersed in the liquid medium $\mathrm{CO}_{2}$ diffusion can be a slow process and limit photosynthetic growth [18]. Cyanobacteria mixotrophy is known to enhance growth rates and photosynthesis efficiency compared to strictly autotrophic or heterotrophic conditions [46]. Moreover, the thinness of the liquid film allows more efficient light transmission. The brewery wastewater treated in this study has a brown/yellow color and subsequently absorbs part of the available light before it radiates the cyanobacterial cells. Radiation absorptivity is proportional to the distance light travels in a material (Beer-Lambert Law) [47]. Thus, reducing the light path offers a significant advantage to the biofilm reactor in comparison to suspended systems where light travels several centimeters through the liquid phase.

\subsection{Biomass Composition}

After cultivation, the attached biomass was scraped off the growth surface and analyzed in terms of carbohydrate, protein, and lipid contents (Figure 5). While inoculum carbohydrate content was $38.4 \%$, the respective content of the harvested biofilm biomass was over $60 \%$ for both surface materials tested. The significantly increased carbohydrate content can be attributed to the extensive nitrogen limitation that occurred in both experiments. Nitrogen is an essential nutrient for protein and nucleic acid synthesis and in cases of shortage cyanobacteria tend to store photosynthetic energy and carbon in the form of glycogen as carbohydrate [48] instead of initiating new cell synthesis. As cultivation progressed protein and lipid contents slightly decreased from $27 \%$ and $4 \%$ to around $22-23 \%$ and $3-3.5 \%$, respectively.

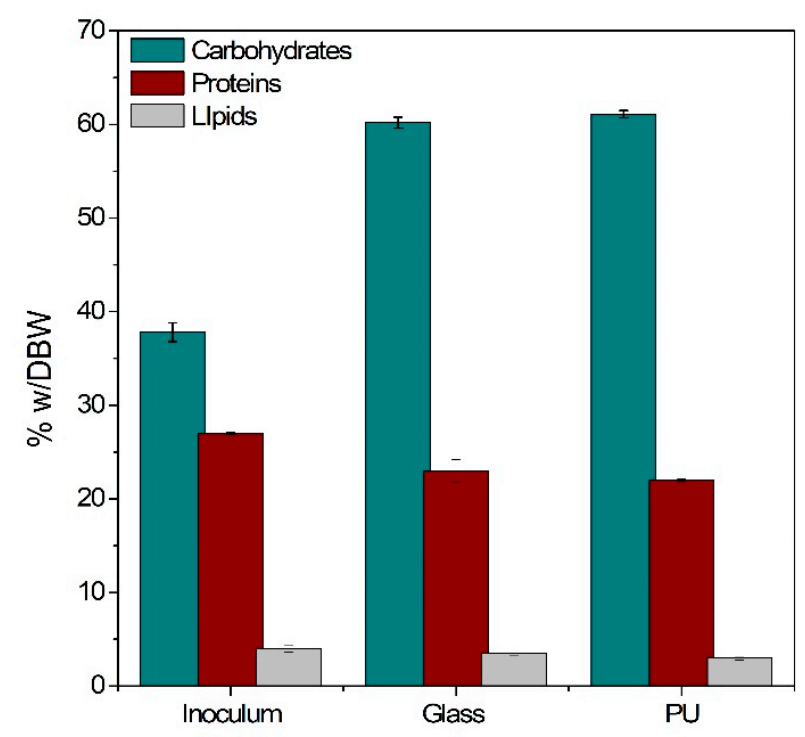

Figure 5. Carbohydrate, protein, and lipid contents of dry biomass weight (DBW) taken from the culture inoculum and the biofilm harvested from glass/polyurethane (PU) growth surfaces.

Papadopoulos et al. reported carbohydrate content of $43.65 \%$ when utilizing the same microbial consortium in suspended cultivation mode for wastewater treatment, despite operating under similar conditions [4]. As discussed in Section 3.2, the cyanobacterial population applied in these experiments secretes large quantities of EPSs (up to $80 \mathrm{mg} \cdot \mathrm{L}^{-1}$ ) under conditions of stress/nutrient limitation. Biomass attachment ensures that a large fraction of these molecules remain within the biofilm matrix instead of dissolving into the wastewater, thus raising the carbohydrate content of the harvested biofilm as cyanobacterial 
EPSs comprise mostly of exopolysaccharides [21]. Therefore, biofilm cultivation could be an effective strategy for carbohydrate-enriched biomass production.

\subsection{Practical Applications and Research Perspectives}

The photosynthetic biofilm approach described in this study could complement conventional brewery wastewater treatment systems such as activated sludge. Life cycle analyses indicate that photosynthetic systems provide a less energy-demanding option ( $47 \%$ operating cost reduction) with a positive environmental impact [49]. The use of biofilms can further enhance the financial viability of photosynthesis-based wastewater treatment facilities as it entails efficient, low-cost, biomass harvesting [23]. The biomass composition of this study's microbial consortium adds a new dimension to the sustainability of the process. Due to its high carbohydrate content, the biofilm biomass can be used as feedstock for bioethanol, a product of significant commercial value [50]. To realize the system's full biotechnological potential more research should be carried out on analyzing the biofilm's EPSs profile, as certain cyanobacterial EPSs could be sustainable source materials for the production of hydrocolloids, bio-sourced materials, and biological agents [21,38].

\section{Conclusions}

A novel biofilm photobioreactor was introduced for brewery wastewater post-treatment. By semi-immersing the biomass within the liquid medium, the flat-plate bioreactor design enabled efficient gas transfer and light transmission that enhanced pollutant removal and biomass production. Both growth surface materials tested (glass/polyurethane) managed to achieve complete biomass attachment ( $>99 \%$ ); however, the hydrophilic material (glass) performed better at the initial stages of microbial adhesion. This finding suggests that for mature cyanobacterial biofilms, the effect of the EPSs produced prevails over the supporting surface hydrophobicity. Biomass harvesting and dewatering are considered the bottleneck that hinders wastewater treatment using algae/cyanobacteria in full-scale applications. The reactor design suggested by the present study successfully addresses these issues without sacrificing water treatment performance or produced biomass quality. Namely, d-COD removal exceeded $70 \%$ for both materials tested, a significant increase compared to suspended cyanobacteria-based systems for brewery wastewater post-treatment. Moreover, due to extensive nitrogen limitation, EPSs retention and efficient irradiation, the harvested biomass accumulated a remarkable carbohydrate content of $61 \%$. The carbohydrate-enriched biofilm could be utilized as a substrate for high yield bioethanol production as well as EPSs extraction. Overall, the results suggest that a flat-plate photobioreactor design using a hydrophilic supporting material could be a simplistic yet efficient approach for sustainable, low-cost, brewery wastewater post-treatment.

Author Contributions: Conceptualization, K.P.P., C.N.E., and D.V.V.; methodology, K.P.P., C.N.E., and A.G.T.; software, K.P.P. and C.N.E.; validation, K.P.P. and C.N.E.; investigation, K.P.P. and C.N.E.; resources, A.G.T. and D.V.V.; data curation, K.P.P. and C.N.E.; writing-original draft preparation, K.P.P. and C.N.E.; writing-review and editing, K.P.P., C.N.E., A.G.T., and D.V.V.; visualization, K.P.P. and C.N.E.; supervision, D.V.V.; project administration, D.V.V.; funding acquisition, K.P.P., C.N.E., A.G.T., and D.V.V. All authors have read and agreed to the published version of the manuscript.

Funding: This study was financially supported by "INVALOR: Research Infrastructure for Waste Valorization and Sustainable Management" (MIS 5002495) which is implemented under the Action "Reinforcement of the Research and Innovation Infrastructure", funded by the Operational Program "Competitiveness, Entrepreneurship and Innovation" (NSRF 2014-2020) and co-financed by Greece and the European Union (European Regional Development Fund).

Institutional Review Board Statement: Not applicable.

Informed Consent Statement: Not applicable.

Data Availability Statement: The data presented in this study are available on request from the corresponding author. The data are not publicly available due to privacy. 
Acknowledgments: The authors gratefully acknowledge Maria Moustaka-Gouni for identifying the microbial community.

Conflicts of Interest: The authors declare that they have no known competing financial interests or personal relationships that could have appeared to influence the work reported in this paper.

$\begin{array}{ll}\text { Abbreviations } & \\ \text { Dissolved Chemical Oxygen Demand } & \mathrm{d}-\mathrm{COD} \\ \text { Total Kjeldahl Nitrogen } & \mathrm{TKN} \\ \text { Nitrate Nitrogen } & \mathrm{NO}_{3}{ }^{-}-\mathrm{N} \\ \text { Nitrite Nitrogen } & \mathrm{NO}_{2}{ }^{-}-\mathrm{N} \\ \text { Ammonium Nitrogen } & \mathrm{NH}_{4}{ }^{+}-\mathrm{N} \\ \text { Orthophosphate Phosphorus } & \mathrm{PO}_{4}{ }^{3-}-\mathrm{P} \\ \text { Extracellular Polymeric Substances } & \text { EPSs } \\ \text { Polyurethane } & \mathrm{PU}\end{array}$

\section{References}

1. Koutra, E.; Economou, C.N.; Tsafrakidou, P.; Kornaros, M. Bio-Based Products from Microalgae Cultivated in Digestates. Trends Biotechnol. 2018, 36, 819-833. [CrossRef] [PubMed]

2. Saratale, R.G.; Kuppam, C.; Mudhoo, A.; Saratale, G.D.; Periyasamy, S.; Zhen, G.; Koók, L.; Bakonyi, P.; Nemestóthy, N.; Kumar, G. Bioelectrochemical systems using microalgae-A concise research update. Chemosphere 2017, 177, 35-43. [CrossRef] [PubMed]

3. Gonçalves, A.L.; Pires, J.C.M.; Simões, M. A review on the use of microalgal consortia for wastewater treatment. Algal Res. 2017, 24, 403-415. [CrossRef]

4. Papadopoulos, K.P.; Economou, C.N.; Dailianis, S.; Charalampous, N.; Stefanidou, N.; Moustaka-Gouni, M.; Tekerlekopoulou, A.G.; Vayenas, D.V. Brewery wastewater treatment using cyanobacterial-bacterial settleable aggregates. Algal Res. 2020, 49, 101957. [CrossRef]

5. Papadopoulos, K.P.; Economou, C.N.; Tekerlekopoulou, A.G.; Vayenas, D.V. Two-step treatment of brewery wastewater using electrocoagulation and cyanobacteria-based cultivation. J. Environ. Manag. 2020, 265, 110543. [CrossRef]

6. Subramaniyam, V.; Subashchandrabose, S.R.; Ganeshkumar, V.; Thavamani, P.; Chen, Z.; Naidu, R.; Megharaj, M. Cultivation of Chlorella on brewery wastewater and nano-particle biosynthesis by its biomass. Bioresour. Technol. 2016, 211, 698-703. [CrossRef]

7. Ferreira, A.; Ribeiro, B.; Marques, P.A.S.S.; Ferreira, A.F.; Dias, A.P.; Pinheiro, H.M.; Reis, A.; Gouveia, L. Scenedesmus obliquus mediated brewery wastewater remediation and $\mathrm{CO}_{2}$ biofixation for green energy purposes. J. Clean. Prod. 2017, 165, 1316-1327. [CrossRef]

8. Posadas, E.; García-Encina, P.A.; Soltau, A.; Domínguez, A.; Díaz, I.; Muñoz, R. Carbon and nutrient removal from centrates and domestic wastewater using algal-bacterial biofilm bioreactors. Bioresour. Technol. 2013, 139, 50-58. [CrossRef]

9. del M. Morales-Amaral, M.; Gómez-Serrano, C.; Acién, F.G.; Fernández-Sevilla, J.M.; Molina-Grima, E. Production of microalgae using centrate from anaerobic digestion as the nutrient source. Algal Res. 2015, 9, 297-305. [CrossRef]

10. de Godos, I.; Blanco, S.; García-Encina, P.A.; Becares, E.; Muñoz, R. Long-term operation of high rate algal ponds for the bioremediation of piggery wastewaters at high loading rates. Bioresour. Technol. 2009, 100, 4332-4339. [CrossRef]

11. Ghimire, A.; Kumar, G.; Sivagurunathan, P.; Shobana, S.; Saratale, G.D.; Kim, H.W.; Luongo, V.; Esposito, G.; Munoz, R. Biohythane production from microalgae biomass: Key challenges and potential opportunities for algal bio-refineries. Bioresour. Technol. 2017, 241, 525-536. [CrossRef] [PubMed]

12. Ganesh Saratale, R.; Kumar, G.; Banu, R.; Xia, A.; Periyasamy, S.; Dattatraya Saratale, G. A critical review on anaerobic digestion of microalgae and macroalgae and co-digestion of biomass for enhanced methane generation. Bioresour. Technol. 2018, 262, 319-332. [CrossRef] [PubMed]

13. Simate, G.S.; Cluett, J.; Iyuke, S.E.; Musapatika, E.T.; Ndlovu, S.; Walubita, L.F.; Alvarez, A.E. The treatment of brewery wastewater for reuse: State of the art. Desalination 2011, 273, 235-247. [CrossRef]

14. Conway, J. Beer Production Worldwide from 1998 to 2019. Available online: https://www.statista.com/statistics/270275 /worldwide-beer-production/ (accessed on 20 December 2020).

15. Amenorfenyo, D.K.; Huang, X.; Zhang, Y.; Zeng, Q.; Zhang, N.; Ren, J.; Huang, Q. Microalgae brewery wastewater treatment: Potentials, benefits and the challenges. Int. J. Environ. Res. Public Health 2019, 16, 1910. [CrossRef] [PubMed]

16. Darpito, C.; Shin, W.S.; Jeon, S.; Lee, H.; Nam, K.; Kwon, J.H.; Yang, J.W. Cultivation of Chlorella protothecoides in anaerobically treated brewery wastewater for cost-effective biodiesel production. Bioprocess Biosyst. Eng. 2015, 38, 523-530. [CrossRef]

17. Molina Grima, E.; Belarbi, E.-H.; Acién Fernández, F.G.; Robles Medina, A.; Chisti, Y. Recovery of microalgal biomass and metabolites: Process options and economics. Biotechnol. Adv. 2003, 20, 491-515. [CrossRef]

18. Mantzorou, A.; Ververidis, F. Microalgal biofilms: A further step over current microalgal cultivation techniques. Sci. Total Environ. 2019, 651, 3187-3201. [CrossRef]

19. Davis, R.; Aden, A.; Pienkos, P.T. Techno-economic analysis of autotrophic microalgae for fuel production. Appl. Energy 2011, 88, 3524-3531. [CrossRef] 
20. Flemming, H.C.; Wingender, J. The biofilm matrix. Nat. Rev. Microbiol. 2010, 8, 623-633. [CrossRef]

21. Cruz, D.; Vasconcelos, V.; Pierre, G.; Michaud, P.; Delattre, C. Exopolysaccharides from cyanobacteria: Strategies for bioprocess development. Appl. Sci. (Switz.) 2020, 10, 3763. [CrossRef]

22. Christenson, L.B.; Sims, R.C. Rotating algal biofilm reactor and spool harvester for wastewater treatment with biofuels by-products. Biotechnol. Bioeng. 2012, 109, 1674-1684. [CrossRef] [PubMed]

23. Morales, M.; Bonnefond, H.; Bernard, O. Rotating algal biofilm versus planktonic cultivation: LCA perspective. J. Clean. Prod. 2020, 257, 120547. [CrossRef]

24. Liu, J.; Wu, Y.; Wu, C.; Muylaert, K.; Vyverman, W.; Yu, H.Q.; Muñoz, R.; Rittmann, B. Advanced nutrient removal from surface water by a consortium of attached microalgae and bacteria: A review. Bioresour. Technol. 2017, 241, 1127-1137. [CrossRef] [PubMed]

25. Muñoz, R.; Köllner, C.; Guieysse, B. Biofilm photobioreactors for the treatment of industrial wastewaters. J. Hazard. Mater. 2009, 161, 29-34. [CrossRef]

26. Gao, F.; Yang, Z.H.; Li, C.; Zeng, G.M.; Ma, D.H.; Zhou, L. A novel algal biofilm membrane photobioreactor for attached microalgae growth and nutrients removal from secondary effluent. Bioresour. Technol. 2015, 179, 8-12. [CrossRef]

27. Körstgens, V.; Flemming, H.C.; Wingender, J.; Borchard, W. Influence of calcium ions on the mechanical properties of a model biofilm of mucoid Pseudomonas aeruginosa. Water Sci. Technol. 2001, 43, 49-57.

28. Zhuang, L.L.; Yu, D.; Zhang, J.; Liu, F.F.; Wu, Y.H.; Zhang, T.Y.; Dao, G.H.; Hu, H.Y. The characteristics and influencing factors of the attached microalgae cultivation: A review. Renew. Sustain. Energy Rev. 2018, 94, 1110-1119. [CrossRef]

29. Irving, T.E.; Allen, D.G. Species and material considerations in the formation and development of microalgal biofilms. Appl. Microbiol. Biotechnol. 2011, 92, 283-294. [CrossRef]

30. Rice, E.W.; Baird, E.W.; Eaton, A.D. Standard Methods for the Examination of Water and Wastewater, 23rd ed.; American Public Health Association: Washington, DC, USA; American Water Works Association: Denver, CO, USA; Water Environment Federation: Alexandria, VA, USA, 2017.

31. Economou, C.N.; Marinakis, N.; Moustaka-Gouni, M.; Kehayias, G.; Aggelis, G.; Vayenas, D.V. Lipid production by the filamentous cyanobacterium Limnothrix sp. growing in synthetic wastewater in suspended- and attached-growth photobioreactor systems. Ann. Microbiol. 2015, 65, 1941-1948. [CrossRef]

32. DuBois, M.; Gilles, K.A.; Hamilton, J.K.; Rebers, P.A.; Smith, F. Colorimetric Method for Determination of Sugars and Related Substances. Anal. Chem. 1956, 28, 350-356. [CrossRef]

33. Choi, S.P.; Nguyen, M.T.; Sim, S.J. Enzymatic pretreatment of Chlamydomonas reinhardtii biomass for ethanol production. Bioresour. Technol. 2010, 101, 5330-5336. [CrossRef] [PubMed]

34. Bradford, M.M. A rapid and sensitive method for the quantitation of microgram quantities of protein utilizing the principle of protein-dye binding. Anal. Biochem. 1976, 72, 248-254. [CrossRef]

35. Bellou, S.; Aggelis, G. Biochemical activities in Chlorella sp. and Nannochloropsis salina during lipid and sugar synthesis in a lab-scale open pond simulating reactor. J. Biotechnol. 2013, 164, 318-329. [CrossRef] [PubMed]

36. Wang, J.H.; Zhuang, L.L.; Xu, X.Q.; Deantes-Espinosa, V.M.; Wang, X.X.; Hu, H.Y. Microalgal attachment and attached systems for biomass production and wastewater treatment. Renew. Sustain. Energy Rev. 2018, 92, 331-342. [CrossRef]

37. Shen, Y.; Zhu, W.; Chen, C.; Nie, Y.; Lin, X. Biofilm formation in attached microalgal reactors. Bioprocess Biosyst. Eng. 2016, 39, 1281-1288. [CrossRef]

38. Delattre, C.; Pierre, G.; Laroche, C.; Michaud, P. Production, extraction and characterization of microalgal and cyanobacterial exopolysaccharides. Biotechnol. Adv. 2016, 34, 1159-1179. [CrossRef]

39. Mazumder, S.; Falkinham, J.O.; Dietrich, A.M.; Puri, I.K. Role of hydrophobicity in bacterial adherence to carbon nanostructures and biofilm formation. Biofouling 2010, 26, 333-339. [CrossRef]

40. Bunce, J.T.; Ndam, E.; Ofiteru, I.D.; Moore, A.; Graham, D.W. A review of phosphorus removal technologies and their applicability to small-scale domestic wastewater treatment systems. Front. Environ. Sci. 2018, 6, 8. [CrossRef]

41. Markou, G.; Vandamme, D.; Muylaert, K. Microalgal and cyanobacterial cultivation: The supply of nutrients. Water Res. 2014, 65, 186-202. [CrossRef]

42. EEC. Council directive concerning urban waste-water treatment. Off. J. Eur. Communities 1991, L 135, 40-52.

43. Tsolcha, O.N.; Tekerlekopoulou, A.G.; Akratos, C.S.; Aggelis, G.; Genitsaris, S.; Moustaka-Gouni, M.; Vayenas, D.V. Biotreatment of raisin and winery wastewaters and simultaneous biodiesel production using a Leptolyngbya-based microbial consortium. J. Clean. Prod. 2017, 148, 185-193. [CrossRef]

44. Tsolcha, O.N.; Tekerlekopoulou, A.G.; Akratos, C.S.; Antonopoulou, G.; Aggelis, G.; Genitsaris, S.; Moustaka-Gouni, M.; Vayenas, D.V. A Leptolyngbya-based microbial consortium for agro-industrial wastewaters treatment and biodiesel production. Environ. Sci. Pollut. Res. 2018, 25, 17957-17966. [CrossRef] [PubMed]

45. Huang, Y.; Xiong, W.; Liao, Q.; Fu, Q.; Xia, A.; Zhu, X.; Sun, Y. Comparison of Chlorella vulgaris biomass productivity cultivated in biofilm and suspension from the aspect of light transmission and microalgae affinity to carbon dioxide. Bioresour. Technol. 2016, 222, 367-373. [CrossRef] [PubMed]

46. Wan, N.; Abernathy, M.; Tang, J.K.H.; Tang, Y.J.; You, L. Cyanobacterial photo-driven mixotrophic metabolism and its advantages for biosynthesis. Front. Chem. Sci. Eng. 2015, 9, 308-316. [CrossRef]

47. Martínez, C.; Mairet, F.; Bernard, O. Theory of turbid microalgae cultures. J. Theor. Biol. 2018, 456, 190-200. [CrossRef] 
48. Möllers, K.B.; Cannella, D.; Jørgensen, H.; Frigaard, N.U. Cyanobacterial biomass as carbohydrate and nutrient feedstock for bioethanol production by yeast fermentation. Biotechnol. Biofuels 2014, 7, 1-11. [CrossRef]

49. Garfí, M.; Flores, L.; Ferrer, I. Life Cycle Assessment of wastewater treatment systems for small communities: Activated sludge, constructed wetlands and high rate algal ponds. J. Clean. Prod. 2017, 161, 211-219. [CrossRef]

50. de Farias Silva, C.E.; Bertucco, A. Bioethanol from microalgae and cyanobacteria: A review and technological outlook. Process Biochem. 2016, 51, 1833-1842. [CrossRef] 